\title{
Effects of climate change on water resources in China
}

\author{
Shourong Wang*, Zuqiang Zhang \\ China Meteorological Administration, No.46, Zhongguancun Nandajie, Haidian District, Beijing 100081, China
}

\begin{abstract}
The average temperature in China has risen by $1.1^{\circ} \mathrm{C}$ from 1908 to 2007 . Temperatures increased from the 1920 s to 1940 s, followed by a decline in the 1950 s to early 1980 s. Temperatures went up again in the mid 1980s, with the 1990s being one of the warmest periods in China in the past 100 yr. Annual precipitation decreased gradually since the 1950s, with an average decline of $2.9 \mathrm{~mm}$ decade $^{-1}$, except for a slight increase from 1991 to 2000. Climate change has had undeniable effects on water resources in China. Over the past $50 \mathrm{yr}$, water distribution patterns have changed over China, especially in major river basins such as the Yangtze and Pearl River basins, where runoff has increased, while in other basins there was a decline. Based on 43 projection results of IPCC GG, GS, $\mathrm{A} 2$ and B2 scenarios, from 2000 on the annual mean air temperature in China will rise by 1.3 to $2.1^{\circ} \mathrm{C}$ by 2020 and 2.3 to $3.3^{\circ} \mathrm{C}$ by 2050 . Annual mean precipitation in China will also increase in the next $50 \mathrm{yr}$, with a projected nationwide increase of 2 to $3 \%$ by 2020 and 5 to $7 \%$ by 2050. Runoff in main river basins will increase, except in some regions such as the Yellow and Hai River Basins. Northern parts of the country that are experiencing rapid socioeconomic development and population growth, however, will be faced with water shortages. To mitigate adverse effects caused by climate variability and changes in water resources, China has implemented strategies such as water saving, structural change in industry, rational water allocation and water transfer projects.
\end{abstract}

KEY WORDS: Water resources - Climate change - Climate impact assessment - Precipitation . River runoff $\cdot$ Water shortage $\cdot$ China

\section{INTRODUCTION}

Most of eastern and southern China is located in the Asian monsoon region. The monsoon climate contributes to the large variation of precipitation across the country, which in turn results in an extremely uneven temporal and spatial distribution of water resources. The summer monsoon climate is characterized by significant rainfall, high temperatures, and a wet summer and autumn, while the winter monsoon has less precipitation, low temperatures, and a dry winter and spring. In general, the drier areas have rainfall for a limited period of time; this can lead to spring droughts and summer floods. The summertime flood runoff accounts for two-thirds of the total annual water resources in the dry areas of the country.

China has an average yearly precipitation of $6 \times$ $10^{12} \mathrm{~m}^{3}$ rainfall. While approximately $3.2 \times 10^{12} \mathrm{~m}^{3}$ of this goes back to the atmosphere either through soil or plant evaporation, the remaining $2.8 \times 10^{12} \mathrm{~m}^{3}$ is retained as surface or ground water. Although China ranks 6th in the world for volume of freshwater per year after Brazil, Russia, Canada, United States and Indonesia, China's per-capita share of $2185 \mathrm{~m}^{3}$ per year is less than one-third of the world's average. The uneven spatial distribution of water resources does not match China's distribution of other resources and productivity. The southern and eastern areas of the country are rich in water resources, while the northern and western areas are not. In addition, the mountain areas receive more precipitation than the plains. The distribution of precipitation across the country drops sharply from $>3000 \mathrm{~mm}$ in the southeast to $<50 \mathrm{~mm}$ in the northwest. The northern part of the country represents $63.5 \%$ of the surface area, $60 \%$ of the arable land (contributing $44 \%$ of the nation's gross domestic prod- 
uct [GDP]), and $46 \%$ of the population, but possesses only $19 \%$ of the water resources.

Over the past $50 \mathrm{yr}$, there was no large variation in surface water and total water resources in China. However, the rainfall distribution pattern changed in this period, with increased river runoff in the south, but noticeably reduced water resources in the north. Some river basins in the north now have a chronic water shortage instead of a seasonal water shortage; this reduces sustainable development significantly. We review recent studies on the effects of climate change on water resources in China to provide guidance for decision makers regarding adaptation and mitigation measures.

\section{CLIMATE CHANGE IN CHINA}

The average surface temperature in China rose by $1.1^{\circ} \mathrm{C}$ from 1908 to 2007 , with the years 1998 and 2007 being the 2 warmest since systematic meteorological observations began in 1951 (PRC 2008). Temperature change in China is in line with global warming, but with some specific characteristics. Mean annual temperature rose from the 1920 s to 1940 s, then declined from 1950 s to 1980 s, and then went up again from the mid 1980s to now. The 1990s marked the warmest period in China over the past $100 \mathrm{yr}$. The warming trend was more obvious in western, eastern and northern China (Wang et al. 2005). Temperatures increased in all seasons, especially in winter ( $>20$ warm winters from 1986 to 2009).

In the past $100 \mathrm{yr}$, there was no obvious trend of annual precipitation change in terms of the whole country; however, there has been a dry trend in the past $50 \mathrm{yr}$, with considerable variation among regions of China. Annual precipitation decreased gradually since the 1950s, with an average decline of $2.9 \mathrm{~mm}$ decade $^{-1}$ (with the exception of a slight increase during the period 1991 to 2000). Annual precipitation decreased significantly in northern and northeastern China, with an average decline of 20 to $40 \mathrm{~mm}$ decade $^{-1}$. Precipitation increased significantly in southern and southwestern China at an average rate of 20 to $60 \mathrm{~mm}$ decade $^{-1}$ (PRC 2008).

Extreme climate phenomena have increased in frequency and intensity. The number of summer heat waves has increased, with more frequent drought events in northern China. Heavy precipitation has increased in southern China, and snow disasters have become more frequent in western China. In coastal zones over the past $30 \mathrm{yr}$, the sea surface temperature and sea level have risen by $0.9^{\circ} \mathrm{C}$ and $90 \mathrm{~mm}$, respectively (PRC 2008).

The trend of climate warming in China will intensify in the future. The annual mean air temperature will in- crease by 1.3 to $2.1^{\circ} \mathrm{C}$ by 2020 and 2.3 to $3.3^{\circ} \mathrm{C}$ by 2050 , respectively, as compared with that in 2000, based on 43 results for IPCC scenarios GG푸 GS $^{\mathbf{2}}$, A2 and B2 (Luo et al. 2005). The magnitude of warming will increase from south to north in China. By 2030, it is estimated that the annual temperature will increase by 1.9 to $2.3^{\circ} \mathrm{C}$ in northwestern China, 1.6 to $2.0^{\circ} \mathrm{C}$ in southwestern China, and 2.2 to $2.6^{\circ} \mathrm{C}$ in the Qinghai-Tibetan Plateau. Precipitation in China is likely to increase during the next $50 \mathrm{yr}$, with a projected nationwide increase of 2 to $3 \%$ by 2020 and 5 to $7 \%$ by 2050 . Southeastern coastal regions will most likely experience the most significant increase in annual rainfall. More frequent extreme weather is likely to have a major effect on socioeconomic development. The arid areas in China are expected to expand, with an increased risk of desertification, and the sea level will likely continue to rise. The glaciers in the Qinghai-Tibetan Plateau and the Tianshan Mountains are retreating at an accelerated rate, and some smaller glaciers are expected to disappear (PRC 2007). Since there are many uncertainties in climate projections, further research and modeling are being implemented in China in step with the IPCC Fifth Assessment Report (AR5).

\section{PAST EFFECTS OF CLIMATE CHANGE ON WATER RESOURCES}

The Pearl, Yangtze, Yellow and Songhua River basins, which are the 4 major river basins from south to north China, exhibited different changing trends in the annual precipitation during the past $50 \mathrm{yr}$ (Ren et al. 2006). Fig. 1 shows the varying trends in the annual precipitation for each river basin from 1956 to 2002. The Pearl and Yangtze River basins became wetter while the other 2 became drier. The precipitation in the Yellow River basin demonstrated the steepest varying trend among the 4 basins.

Fig. 2 demonstrates that the runoff of the Yangtze and Pearl River basins increased, while the runoff declined for the Yellow and Songhua River basins; this was consistent with the changes in precipitation in spite of additional anthropogenic influences. Table 1 shows the specific observed runoff data of the Yangtze, Yellow, Pearl and Songhua Rivers. Compared with the $1960 \mathrm{~s}$, the observed mean annual runoff in the 1990s increased 12.6 and $9.6 \%$, respectively, at the Gaoyao station, located on the lower reaches of the Pearl River, and at the Datong hydrometric station, located on the

1GG: an IS92a Greenhouse Gas scenario that does not include the effects of sulphate aerosols.

${ }^{2}$ GS: an IS92a Greenhouse Gas scenario that includes the effects of sulphate aerosols. 

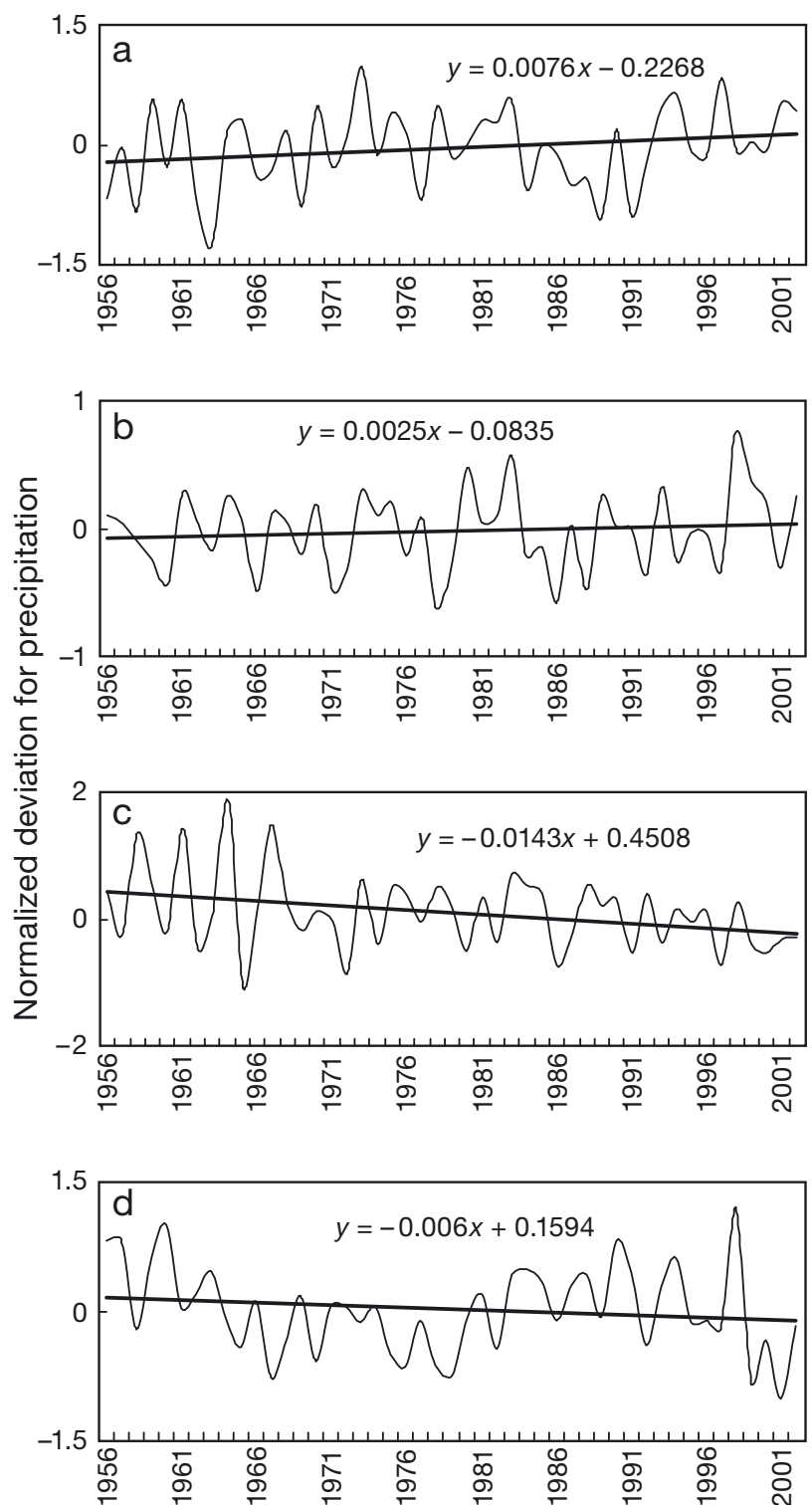

Fig. 1. Normalized annual mean precipitation over the 4 major river valleys in China during 1956-2002: (a) Pearl, (b) Yangtze, (c) Yellow and (d) Songhua. After Ren et al. (2006)

lower reach of the Yangtze River. During the same period, the runoff at Huayuankou station on the lower reach of the Yellow River and at Jiamusi station on the lower reach of the Songhua River decreased 30 and $6.5 \%$, respectively (Cao et al. 2006).

As demonstrated in Table 2 (Cao et al. 2006), one of the most significant features of water resource changes in China was the rapidly declining precipitation and runoff in all basins in the north. As compared to 1956-1979, precipitation in the Hai-Luan, Yellow and Huai River basins was reduced by $8.0,11.0$ and $8.1 \%$, respectively, and runoff decreased 25.4, 22.7 and $24.0 \%$, respectively, in 1994-1999. These observed decreases in river runoff were due to the combined influ-
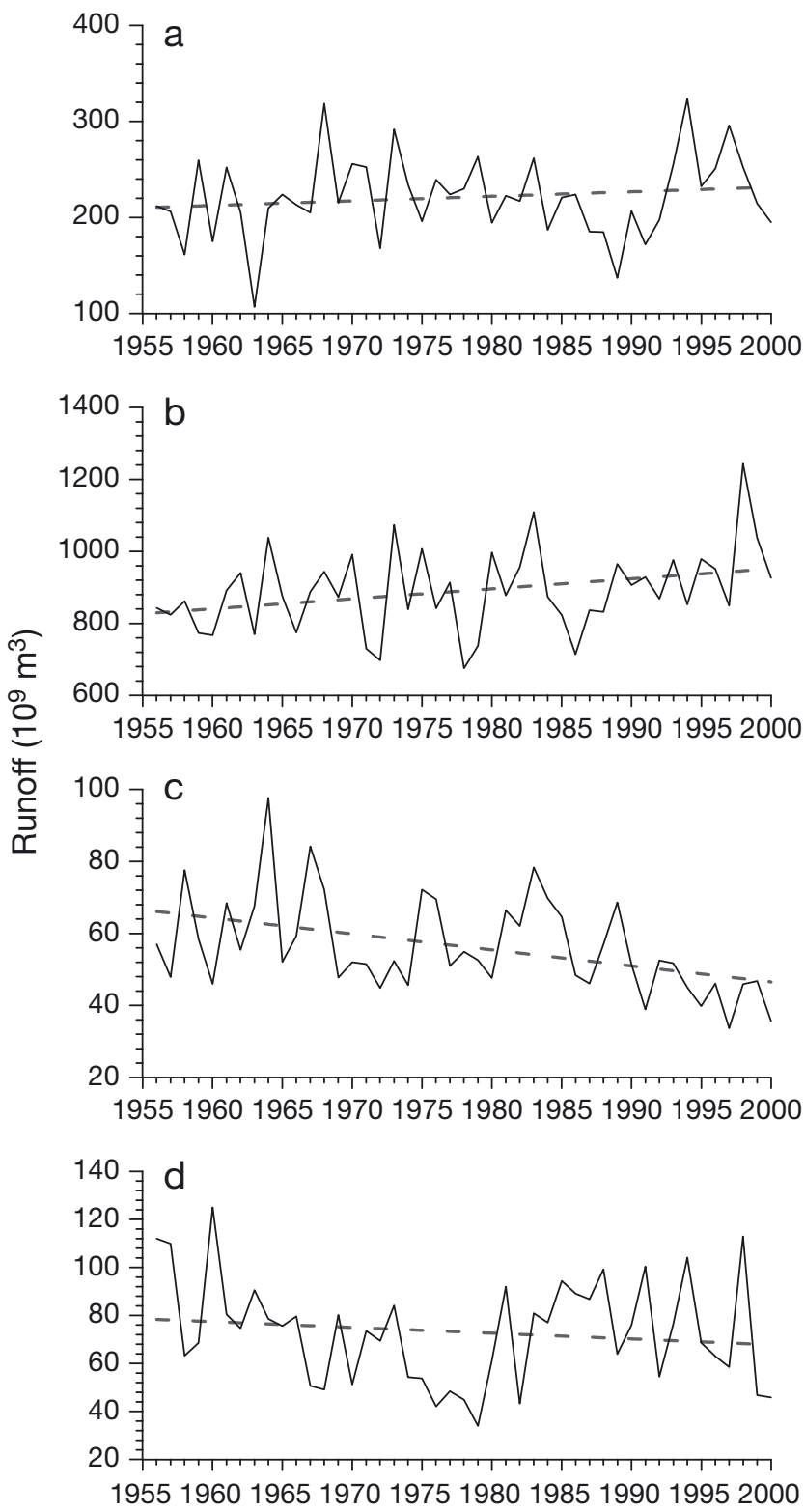

Fig. 2. Variation in observed runoff of the 4 major rivers in China: (a) Pearl, (b) Yangtze, (c) Yellow and (d) Songhua River. Dashed lines are the derived linear trends (after Cao et al. 2006)

Table 1. Observed runoff in the 4 major rivers in China. Comparisons are available only for specific periods during the 1960s to 1990s. More comparisons with standard periods are necessary in IPCC AR5. Source: Cao et al. (2006)

\begin{tabular}{|lcccr|}
\hline River & $\begin{array}{c}\text { Hydrometric } \\
\text { station }\end{array}$ & $\begin{array}{c}\text { Runoff in the } \\
\text { 1960s }\left(10^{9} \mathrm{~m}^{3}\right)\end{array}$ & $\begin{array}{c}\text { Runoff in the } \\
\text { 1990s }\left(10^{9} \mathrm{~m}^{3}\right)\end{array}$ & $\begin{array}{c}\text { Change } \\
(\%)\end{array}$ \\
\hline Pearl & Gaoyao & 213 & 240 & +12.6 \\
Yangtze & Datong & 876 & 960 & +9.6 \\
Yellow & Huayuankou & 65 & 45 & -30.7 \\
Songhua & Jiamusi & 78 & 76 & -3.1 \\
\hline
\end{tabular}


Table 2. Reduced precipitation and runoff in some major northern river basins. Comparisons available only for 1956-1979 and 1994-1999. More comparisons with standard periods are necessary in IPCC AR5. Proportion percentage of annual runoff to the sea relative to total annual runoff; abs.: absolute; na: not available. Source: Cao et al. (2006)

\begin{tabular}{|c|c|c|c|c|c|c|}
\hline Basin & Period & $\begin{array}{c}\text { Annual } \\
\text { precipitation (mm) }\end{array}$ & \multicolumn{3}{|c|}{$\longrightarrow$ Annual runoff } & $\begin{array}{c}\text { Proportion } \\
(\%)\end{array}$ \\
\hline Hai-Luan & $1956-1979$ & 560 & 90.5 & 28.8 & 16.0 & 55.5 \\
\hline & $1994-1999$ & 515 & 67.5 & 21.5 & 7.6 & 35.0 \\
\hline $\begin{array}{l}\text { Change } \\
\text { (abs.) (\%) }\end{array}$ & & $\begin{array}{l}-45 \\
-8\end{array}$ & $\begin{array}{c}-23 \\
-25.4\end{array}$ & $\begin{array}{c}-7.3 \\
-25.4\end{array}$ & $\begin{array}{c}-8.4 \\
-52.5\end{array}$ & \\
\hline Yellow & $1956-1979$ & 464 & 83.2 & 66.1 & 41.0 & 62.0 \\
\hline & 1994-1999 & 413 & 64.3 & 51.1 & 11.7 & 22.9 \\
\hline Change & & -51 & -18.9 & -15.0 & -29.3 & \\
\hline (abs.) (\%) & & -11 & -22.7 & -22.7 & -71.5 & \\
\hline Huai & 1956-1979 & 860 & 225.1 & 74.1 & 59.1 & 80 \\
\hline & $1994-1999$ & 790 & 172.2 & 56.3 & 30.9 & 54.9 \\
\hline Change & & -70 & -52.9 & -17.8 & -28.2 & \\
\hline (abs.) $(\%)$ & & -8.1 & -24 & -24 & -47.8 & \\
\hline
\end{tabular}

ence of climate variability and anthropogenic activity (in particular as a result of socioeconomic development). Wang et al. (2008) suggest that climate change accounts for roughly $38.5 \%$ of the runoff reduction over the past $50 \mathrm{yr}$ for the middle Yellow River basin.

\section{WATER RESOURCE CHALLENGES}

\subsection{Effect of climate change on water distribution}

Under the IPCC climate change scenarios SRES A2 and B2, China can expect an increase in both average temperature and precipitation in the coming 50 to $100 \mathrm{yr}$, compared to the reference period 1961 to 1990 (Zhang et al. 2005); this will have significant impacts on hydrology and water resources (Wang et al. 2002a,b). Fig. 3 demonstrates that there will be a noticeable drop in average runoff in some northern areas such as Ningxia, Gansu, Shaanxi, Shanxi and Hebei, and an increase in parts of southern areas such as Hubei, Hunan, Jiangxi, Fujian, Guangxi,

Fig. 3. Multi-year (2071-2090) average variation in runoff under A2 (top) and B2 (bottom) climate change scenarios, compared to the reference period (1961-1990) (Zhang et al. 2005); parentheses: no. of boxes for each category. Comparisons are available only for specific periods during the 1960 s to 1990 s
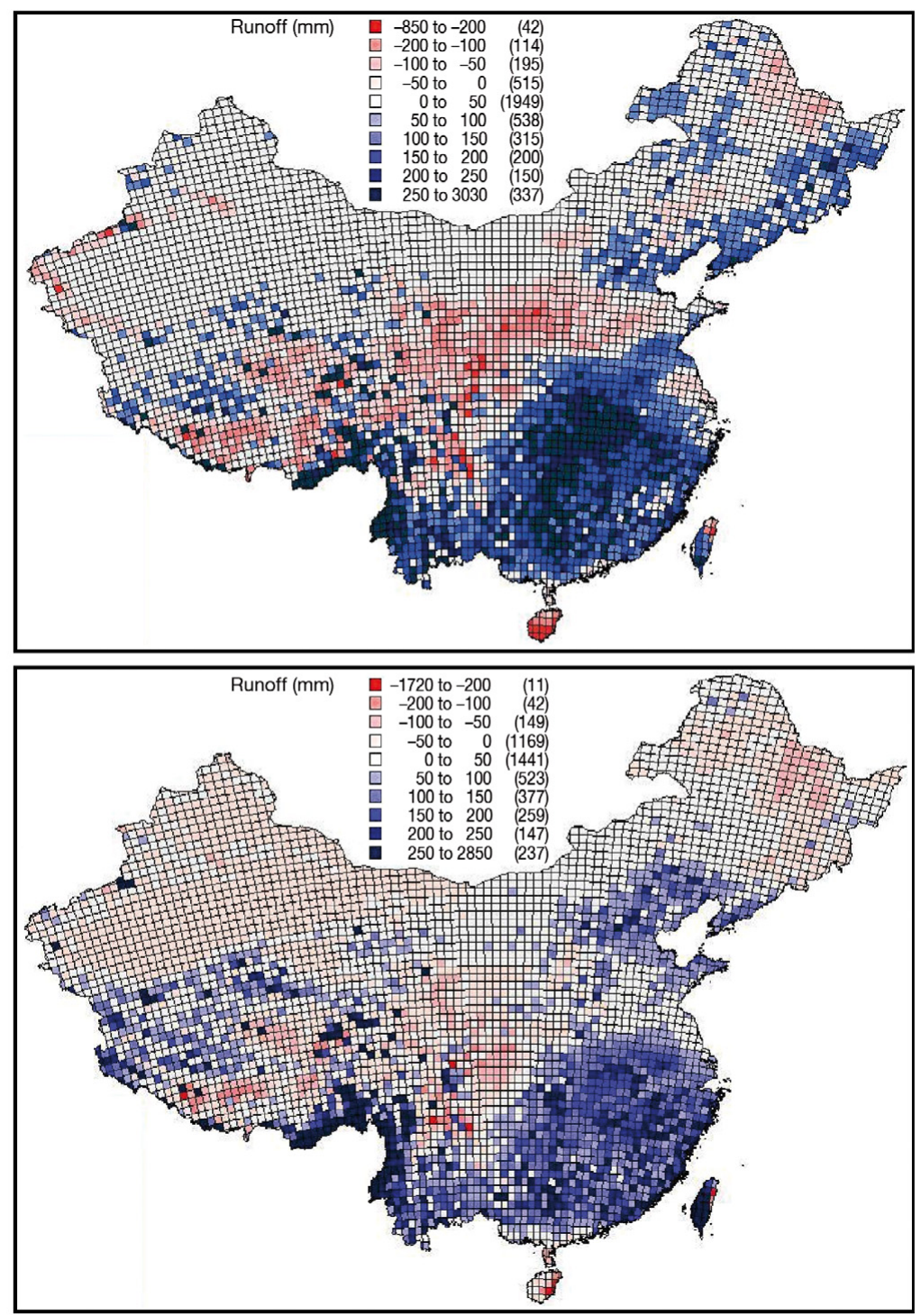
Table 3. Projections of water shortage $\left(10^{9} \mathrm{~m}^{3}\right)$ in China in the cases of normal and dry years, respectively, by 2030 due to climate change alone, population growth plus socioeconomic development alone, and their combined effects. GCMs used: GISS (NASA), LINL (Lawrence Livermore National Laboratory), UKMOH (Hadley Centre), OSU (Climate Research Institute, Oregon State University)

\begin{tabular}{|c|c|c|c|c|c|c|}
\hline \multirow[t]{2}{*}{ Region } & \multicolumn{2}{|c|}{$\begin{array}{l}\text { Due to } \\
\text { climate } \\
\text { change }\end{array}$} & \multicolumn{2}{|c|}{$\begin{array}{l}\text { Due to population } \\
\text { growth plus socioeco- } \\
\text { nomic development }\end{array}$} & \multicolumn{2}{|c|}{$\begin{array}{l}\text { Combined } \\
\text { effects }\end{array}$} \\
\hline & Normal & Dry & Normal & Dry & Normal & Dry \\
\hline $\begin{array}{l}\text { Beijing-Tianjin- } \\
\text { Tangshan area }\end{array}$ & 0.16 & 1.43 & 1.53 & 3.61 & 1.37 & 5.04 \\
\hline Hai-Luan basin & 0.69 & 9.48 & 25.20 & 47.76 & 25.09 & 57.24 \\
\hline Yellow River basin & 0.19 & 12.12 & 13.51 & 24.34 & 13.32 & 36.46 \\
\hline Huai basin & 0.44 & 3.54 & 3.60 & 15.92 & 2.84 & 19.46 \\
\hline
\end{tabular}
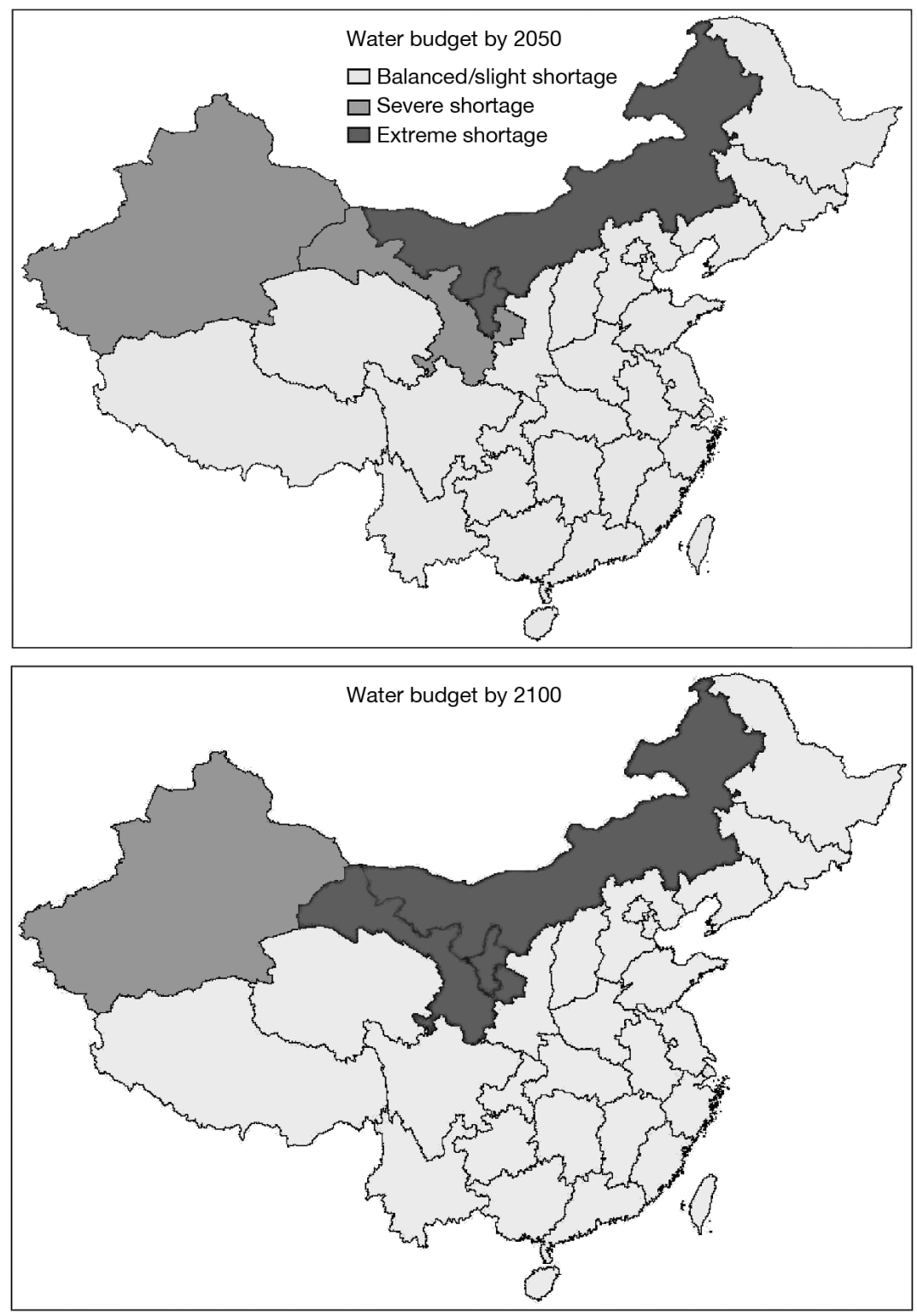

Fig. 4. Distribution of water shortage under scenario A2 by 2050 (top) and by 2100 (bottom) (Zhang et al. 2005)
Guangdong, and Yunnan; this suggests that there will be more floods in the south and more drought events in the north. Meanwhile, the Yellow and HaiLuan river basins will suffer further water shortages, while the lower and middle reaches of the Yangtze and Pearl river basins will have more flood disasters.

Climate change will alter future distribution of water resources along with changes in precipitation, increased melting of glaciers and enhanced evaporation due to climate warming. According to modeling projections (Shi \& Liu 2005, Li et al. 2002), the glaciercovered area in western China will be reduced by $27 \%$ in 2050, and ice reserves in the western mountains will decline by one-fourth, resulting in more melting water from glaciers until 2050, and less after this, because of a reduction in glacial extent.

\subsection{Water shortages in northern basins}

At the same time that the warming climate decreases river runoff, it will also lead to an increase in irrigation requirements for agricultural land, since climate change affects the potential evaporation during the crop growing season, which can reduce soil moisture. For example, the annual amount of irrigation water required in the Huang-Huai-Hai Plain is expected to increase by 66 to $84 \%$ if there is a $20 \%$ decrease in annual rainfall (Zhang et al. 2009), resulting in major water shortages. According to Liu (1997), by 2030 there will be water shortfalls in normal years, as well as in dry years in northern basins. Population growth and socioeconomic development will intensify the water shortage (Table 3 ).

\subsection{Water vulnerability in the north}

Fig. 4 shows the vulnerability analysis regarding the effects of climate change on water resources under the A2 scenario. If water resources are utilized in a sustainable manner, most of China will broadly achieve a balance between 
Table 4. Variations in runoff, per capita water resources and water shortage rate, all in percentage, relative to the reference period (1961-1990) in north provinces of China under IPCC scenarios A2 and B2

\begin{tabular}{|lcccc|}
\hline Regions & Runoff & Per capita water resources & Shortage rate & Assessment \\
\hline Ningxia and Gansu & -6 to -10 & -30 to -40 & 4 to 8 & Severe water shortage \\
Shanxi and Shaanxi & -2 & -20 to -30 & 0 & Potential water shortage \\
Xinjiang and Inner Mongolia & 12 to 17 & -11 to -30 & 3 to 6 & Severe water shortage \\
\hline
\end{tabular}

water demand and supply, except for Inner Mongolia, Xinjiang, Ningxia and Gansu, where water shortage is expected to reach 4 to $7 \%$ of the required water quality by 2050 , and 6 to $8 \%$ by 2100 .

It is projected that over the next 50 to $100 \mathrm{yr}$, taking both climate change and population growth into account, per capita water shortage will become worse in most of the northern regions such as Ningxia and Gansu, Xinjiang and Inner Mongolia, Shanxi and Shaanxi, with a per capita water-resource decrease of 11 to $40 \%$ (Table 4 ).

\section{CONCLUSIONS}

Climate has been changing in China for the past $100 \mathrm{yr}$, which had significant effects on hydrology and water resources. It is projected that in the next 50 to $100 \mathrm{yr}$, taking both climate change and population growth into account, water shortages will become more serious in northern areas such as Qinghai, Shanxi, Shaanxi, Ningxia, Xinjiang and Gansu. In order to adapt to climate change and to lessen its effects on water resources in China, strategies such as water-saving plans, water rationing and the recycling of contaminated water have been adopted, and engineering projects such as the project transferring water from southern to northern China, have been implemented.

\section{LITERATURE CITED}

Cao JT, Ren GY, Jiang T (2006) Variation trends in the runoffs of the four major rivers in China. In: Ren GY (ed) Climate change and China's water resources. China Meteorological Press, Beijing, p 219-233 (in Chinese)

Li PJ, Liu SY, Guo DX (2002) Projection on the change of the frozen layer. In: Ding YH (ed) Projections on the change of environment in the western China. Science Press, Beijing p 166-189

Liu CZ (1997) Potential impact of climate change on hydrology and water resources in China. Advances in Water Science 8:220-225 (in Chinese)

Luo Y, Ding YH, Zhao ZC, Gao XJ, Xu Y, Xie ZR (2005) Projection of the anthropologic impacts on climate change. In: Qin DH (ed) Climate and environment evolutions in China. Science Press, Beijing, Vol I, p 507-555 (in Chinese)

PRC (People's Republic of China) (2007) China's national climate change programme. National Development and Reform Commission, Beijing. Available at: http://www. ccchina.gov.cn/WebSite/CCChina/UpFile/File188.pdf

PRC (People's Republic of China) (2008) China's policies and actions for addressing climate change. Information Office of the State Council of the People's Republic of China, Beijing (in Chinese)

Ren GY, Zhang L, Guo J (2006) Variation trends in the runoffs of the 4 major rivers in China. In: Ren GY (ed) Climate change and China's water resources. China Meteorological Press, Beijing, p 47-90 (in Chinese)

Shi YF, Liu SY (2005) Projection on the response of the glaciers in China to the global warming in 21 Century. Chin Bull Sci 45:434-438 (in Chinese)

Wang GQ, Zhang JY, Liu JF, He RM (2008) Quantitative assessment for climate change and human activities impact on river runoff. China Water Resource 2008(2):55-58 (in Chinese)

Wang SR, Huang RH, Ding YH, Leung LR, Wigmosta MS, Vail LW (2002a) Improvement of a distributed hydrology model DHSVM and its climate-hydrology off-line simulation experiment. Acta Meteorol Sinica 16:374-387

Wang SR, Huang RH, Ding YH, Leung LR, Wigmosta MS, Vail LW (2002b) Numerical simulation experiments by nesting hydrology model DHSVM with regional climate model RegCM2/China. Acta Meteorol Sinica 16:509-518

Wang SW, Wu RS, Yang XQ, Zai PM (2005) Climate change in China. In: Qin DH (ed) Climate and environment evolutions in China, Vol I. Science Press, Beijing, p 63-103 (in Chinese)

Zhang JY, Wang GQ, Yang Y, He RM, Liu JF (2009) Impact of climate change on water security in China. Adv Clim Change Res 5(Suppl.):34-40 (in Chinese)

Zhang SL, Li Y, Liu CZ 2005) Distribution of the vulnerability of the water resources system in China. In: Qin DH (ed) Climate and environment evolutions in China. Science Press, Beijing, Vol II, p 104-109 (in Chinese) 